\title{
MEMOIR
}

\section{GEORGE GREEN}

George Green was born in Stockport in June 1875 and died in Bromley on Christmas Eve, I955. His formal education began at Stockport Grammar School, whence, after passing the London Matriculation Examination with honour, he won Mathematical Scholarships both to Christ's College and St John's College, in the University of Cambridge. He chose Christ's College, and thus began an association continued, to his delight, by his son and his grandson. He was twenty-second Wrangler in the Mathematical Tripos and was minded to enter the Indian Civil Service, but, in deference to the wish of his parents, he decided to make a career in England.

In 1897 , he joined the staff of the Joint Mortality, 1863-93, Investigation at the Institute and a year later was appointed Assistant Supervisor under T. G. Ackland. The staff celebrated a notable British victory in the Boer War by persuading S. H. Jarvis to sing the National Anthem into the telephone connecting the Office with the Hall, while those working there joined in. Momentary embarrassment occurred when the Chaiman of the Scottish Section of the Mortality Committee entered, but they all adjourned to the 'Cheshire Cheese' for lunch; one who took part remembers that Green was the soul of the party.

Exempted from Part I of the Institute's Examinations, Green obtained his Fellowship in 1905 and, thereafter, his professional Alma Mater, as is her wont with favourite sons, took him to herself, loading him with work and honour. From 1909 to 1914 he was the Official Tutor for Part I, jointly with his friend from Cambridge days, T. P. Thompson, B.A. Then, for several years, he was a member and for a time Honorary Secretary of the Board of Examiners.

In 1926, Green joined the Council, on which he served until 1943. He received the distinctions of appointment as an Honorary Secretary for two years, as a Vice-President for four years and as Treasurer for two years. Always keenly interested in professional education, he took a leading part in the prolonged investigation that resulted in the thorough revision of the Institute's Syllabus of Examinations and in the establishment in $1937^{\text {mas a }}$ a joint concern of the Institute and the Faculty-of the Actuarial Tuition Service. As DeputyChairman of the London Committee, he worked long and hard in placing the new venture firmly on its feet.

He was a member of the Permanent Committee of International Congresses of Actuaries and took a large shate in what was, to some, the internationally depressing subject of revision of actuarial notation. This matter was debated at the 1934 Congress in Rome, where certain British members were formed into a small team of speakers under the energetic control of the President of the Institute. Green and another, being required to produce proper notes in advance, were allotted the secretarial assistance of a young lady who informed them at once that, though 'quarter-English', she did not like the race. Green, unabashed, remained with her while his unwilling colleague was sent in search of flowers and then she changed her mind.

Green joined the staff of the 'Union' in 1900, becoming Assistant Actuary in I912 and Actuary in 1932 . He was destined, however, to be called to an even 
wider task: in 1938, Henry Brown, whose health had broken down during his Presidency of the Institute, had to retire from his position as Actuary of the 'Commercial Union', and the Directors of that Office summoned Green to be the successor. He remained so until his official career ended by retirement in December 1943 .

A full and an honourable record-but it omits so much of a many-sided man and a wonderful friend; what else shall be said in the confines of this brief memoir? He was a good lacrosse player, a keen Freemason-a Past Master of his Lodge-and a successful amateur gardener who knew much more than most persons in that category. Then there was his service in the First World War: he began work with the British Red Cross Society Ambulance Column (City of London Detachment) whose members devoted themselves to meeting and caring at any hour of the night for the piteous casualties of the battlefield brought back to the London railway termini. What he saw there impelled him in 1915 , though over 40 , to join the Inns of Court O.T.C., from which he was commissioned to the 4 th/5th Loyal North Lancashire Regiment. He went to France, was promoted Captain and commanded his Company at Paschendaele where, in October 1917, he was severely wounded. Struck by shrapnel in the neck, he was being assisted after several hours to the dressing station, leaning on two orderlies, when a shell killed one of them and wounded Green again. Brought back to England, he emerged from an interval of unconsciousness to be welcomed, by happy coincidence, at a London terminus by some of his former Red Cross colleagues. Having recovered, he was posted to an antiaircraft station at Portsmouth where he did highly technical work on soundranging.

For many years, Green kept in close touch with his old regiment and travelled to Bolton to attend its reunions. There is good reason, too, for believing that, in his own way, he gave quiet succour to comrades with whom life had dealt specially hardly. He was the first Chairman of the House Branch of the British Legion, established in the 'Commercial Union' and its associated offices.

Until he had a severe illness some five years ago, Green was remarkably young in appearance; he came through with characteristic courage and, though obviously enfeebled in body, remained blithe in spirit and keen in mind. In honour of his 8oth birthday, the Actuaries Club made its member its guest in June r955, and he spoke with all his former gay and gentle precision.

Now, full of years and faith and honour, he has left his happy domestic scene and the many who rejoiced to know him. He wore his great distinction with beautiful modesty and his memory will be as his name.

R.C.s. 